\title{
THE GROUND VEGETATION MANAGEMENT OF WOOD- PASTURES IN ROMANIA - INSIGHTS IN THE PAST FOR CONSERVATION MANAGEMENT IN THE FUTURE
}

\author{
KINGA ÖLLERER \\ Institute of Biology Bucharest - Romanian Academy \\ Spl. Independentei 296, 060031 Bucharest, Romania, PO Box: 56-53 \\ (phone: +40-21-221-9202; fax: +40-21-221-9071) \\ e-mail: kinga.ollerer@gmail.com \\ (Received $5^{\text {th }}$ Apr 2014 ; accepted $22^{\text {nd }}$ July 2014)
}

\begin{abstract}
Wood-pastures are important elements of the European natural and cultural heritage, fulfilling several ecological functions at local and landscape scale (e.g. providing a valuable habitat for a wide range of species, as well as a link to traditional landscape management practices), but are nowadays in decline especially due to land-use changes begun in the 20th century and lack of legal recognition. Woodpastures are relatively common in Southern Transylvania (Romania), and, contrary to the majority of similar habitats from Europe, are not threatened mainly by abandonment and subsequent secondary succession, but by modifications in the traditional management regime. Using a wide range of historical documents, this paper presents an overview of the traditional and the current management of the ground vegetation in wood-pastures. These habitats were traditionally grazed mainly by cattle and pigs, sheep being often subject to regulations. Regular mowing was also practiced. Nowadays sheep are the main grazers and mowing has practically disappeared, while the incidences of burning are increasing. Analyzing the differences between the present situation and those described in old publications provides valuable information for conservation management and potential restoration of similar, degraded habitats throughout Europe.
\end{abstract}

Keywords: traditional practices, grazing, mowing, pasture burning, Transylvania

\section{Introduction}

Animal husbandry adapted to the landscape is a historical determinant of the character of the European vegetation (Behre, 1988). As scientific data accumulates regarding the high biodiversity and conservation value of semi-natural habitats (Halada et al., 2011), traditional management practices that created and continue to maintain these exceptionally biodiverse areas, and the associated historical, social and psychological factors, tend to be considered as integral elements of conservation management in the present context of biodiversity loss (Fischer et al., 2012; Middleton, 2013; Whiteman and Copper, 2002, Szentes et al., 2011, 2012; Saláta et al., 2011). Attention is turned towards landscapes and regions that still retain their traditional usage, both because of the high number and diversity of species they harbor, and because of their potential role as reference sites for conservation management and restoration (Babai and Molnár, 2014).

Farmland biodiversity is exceptionally rich in the Transylvanian region of Romania, due to the ongoing use of traditional practices, and a substantial part of the region is represented by high nature value farmland, retaining biodiversity in good conservation status (Akeroyd and Page, 2006; Mikulcak et al., 2013; Schmitt and Rákosy, 2007).

Agro-silvo-pastoral systems, the deliberate combination of growing trees and agriculture (mainly pasturing) are recognized for delivering economic benefits (e.g. 
agricultural and non-timber forest products) and valuable ecosystem services (Bergmeier et al., 2010; Rigueiro-Rodríguez et al., 2009; Rois-Díaz et al., 2006).

Wood-pastures are one example of such systems. Due to their transitional character and structural diversity, emerging from the presence of (veteran) trees (Lindenmayer et al., 2012) scattered (Manning et al, 2006; Fischer et al., 2010) across an open landscape maintained by a long-established tradition of grazing (Stiven, 2009), wood-pastures are providing conditions for the maintenance of both open habitat and forest-dependent species and play an important role in enhancing biodiversity (Bergmeier et al., 2010; Rich et al., 2005). Wood-pastures are deliberately shaped mosaic-like areas, bearing a characteristic biodiversity and representing living documents of land-use and cultural history (Rotherham, 2013). These semi-natural habitats require specific and active management, the seizure or modification of the maintaining practices leading to major changes in their character (Bugalho et al., 2011; Rotherham, 2013).

Wood-pasturing was widespread also in Central-East Europe until few decades ago, when it was gradually abandoned following changes in agricultural and forestry regulations, as a consequence of increasing demand for crop and timber production (Saláta et al., 2009). National inventories are scarce, and those that exist (ex. Haraszthy et al., 1997 for Hungary) have confirmed that wood-pastures are one of the most threatened habitats in Europe, having lost their complex usage and being present nowadays only as a historical or neglected land-use (Bergmeier et al., 2010). Albeit these general trends, wood-pastures are shown to be relatively common in Southern Transylvania, Romania (Hartel et al., 2013), and, contrary to the majority of similar habitats from Europe, are not threatened by abandonment and subsequent secondary succession or intensification (Bergmeier et al., 2010), but by modifications in the traditional management regime (Hartel et al, 2013; Öllerer, 2013).

In a time when wood-pastures are of increasing relevance due to their integration of ecological, economical (mainly agricultural) and social interests, the management methods and experiences shared by the contemporary practitioners, or by those from older times, represent an invaluable source of information. A great amount of information regarding the creation and use of wood-pastures lies in old documents and publications dating from the period when this land-use was still valued and widely practiced. This study relies on field observations and on such old publications.

The aim of this paper is twofold. First, it intends to contribute to the general knowledge regarding wood-pastures by discussing the social-historical, economical and ecological aspects of the management of this habitat type, through the case study of Southern Transylvania. Second, it brings in attention the scientific and conservation importance of traditional management practices that are relevant for the management of this habitat type. The paper concludes with implications for conservation management by stressing out the importance of creating the necessary conditions (e.g. policies, economical regulations, transfer of knowledge underlying traditional land-use) that promote the maintenance of traditional practices on which relies the future of these unique and highly biodiverse habitats. 


\section{Material and methods}

\section{Study area}

\section{General description of the study area}

The study was conducted in the southern part of the Transylvanian Plateau, Romania. The region is ethnographically distinct, being inhabited from the $12^{\text {th }}$ century onwards by the Transylvanian Saxons. They were granted administrative and religious autonomy upon their arrival, which was mostly maintained up to the $18^{\text {th }}$ century, however they continued to be a rich and influential population segment up to the second decade of the $20^{\text {th }}$ century (Gündisch, 1998). The landscape management practices applied by the colonists were those brought from the present-day Germany and Luxembourg and were based on strict rules (Nägler et al., 1994; Schuller, 1895), a result of which Saxon farming and forestry was seen as exemplary and sustainable as soon as the accelerated pace of land-use change reached Transylvania in the $19^{\text {th }}$ century (Dorner, 1910).

The study area is partially overlapping with the Natura 2000 Sighişoara-Târnava Mare Site of Community Importance (SCI), the largest representative of the continental biogeographical region in Romania (EEA, 2008; Fig. 1). The region is predominantly rural, settlements being scarce and mostly villages. Habitats are generally wellmaintained but locally threatened by abandonment, over-grazing, illegal loggings and spring pasture burnings etc. (Akeroyd and Page, 2006; Fischer et al., 2012).

The predominant geomorphological units are the gently rolling, mainly forested hills of about $550 \mathrm{~m}$ a.s.l. mean altitude. The climate is continental, with a mean annual temperature of $8.8^{\circ} \mathrm{C}$, indicating a relatively low temperature potential. Annual rainfall is about $650-700 \mathrm{~mm} / \mathrm{sqm}$, with peaks in the May-June period (Oroian, 2009).

The characteristic primary vegetation is represented by mixed Oak (Quercus petraea) and Hornbeam (Carpinus betulus) and mixed Beech (Fagus sylvatica) and Hornbeam forests. The former can be found mainly on flat areas (hilltops, plateaus) and on slopes with southern exposition, while the latter are predominant on slopes with northern exposition (Coldea, 1992). The secondary vegetation installed after the removal of these forests, therefore the potential vegetation of wood-pastures is characteristically Festuco rubrae-Agrostetum capillaris Horvat (1951) 1952 and Anthoxantho-Agrostietum capillaris Sillinger 1933 on hilltops, respectively AgrostioFestucetum valesiacae Ardelean on the more sunny slopes 1983 (Coldea, 1992).

\section{Wood-pastures}

Recent studies have shown that wood-pastures are common in this region (Hartel and Moga, 2010 reported 37; Hartel et al., 2013 reported 42; while the latest list comprises 55 wood-pastures: Roellig et al., 2013; Fig. 1). 31 out of the 42 wood-pastures surveyed by Hartel et al. (2013) were classified as ancient (contained veteran trees), showing the historical character of these sites. 31 out of the 55 wood-pastures are covered by Natura 2000 regulations and the entire study area is included in the High Nature Value (HNV) farming systems category. Wood-pastures have an average area of 100 ha (Hartel et al., 2013), are characteristically situated on slopes with low inclination (2-15\%) and mainly northern exposition (NE, E, NV, V, N), and sometimes on plateaus (Holban, 2011). From a land-use and legal perspective, most wood-pastures are included in the pastures and meadows category as "pastures with trees" and "wooded pastures" (Law 46/2008, 
Law 2014/2011), but without any recognition of the keystone role of the scattered trees (Manning et al., 2006), or recommendations for their maintenance and recruitment.

The best known and most studied wood-pasture is the Breite, located approximately at the centre of the overall study area (Fig. 1). Tree cover is characteristic for open wood-pastures, accounting for less than $7 \%$ of the 133 ha area (Moga et al., 2009). The reasons for addressing the Breite more in detail were the existing detailed knowledge regarding ground vegetation and management history (Öllerer, 2012; 2013), and availability of data on its biodiversity (see Hartel et al., 2013 for a synthesis of studies and species numbers). The number of species identified up to date considered threatened, rare or protected at national (Red Lists) and international level (IUCN, EU Birds and Habitats Directives) is about 140.

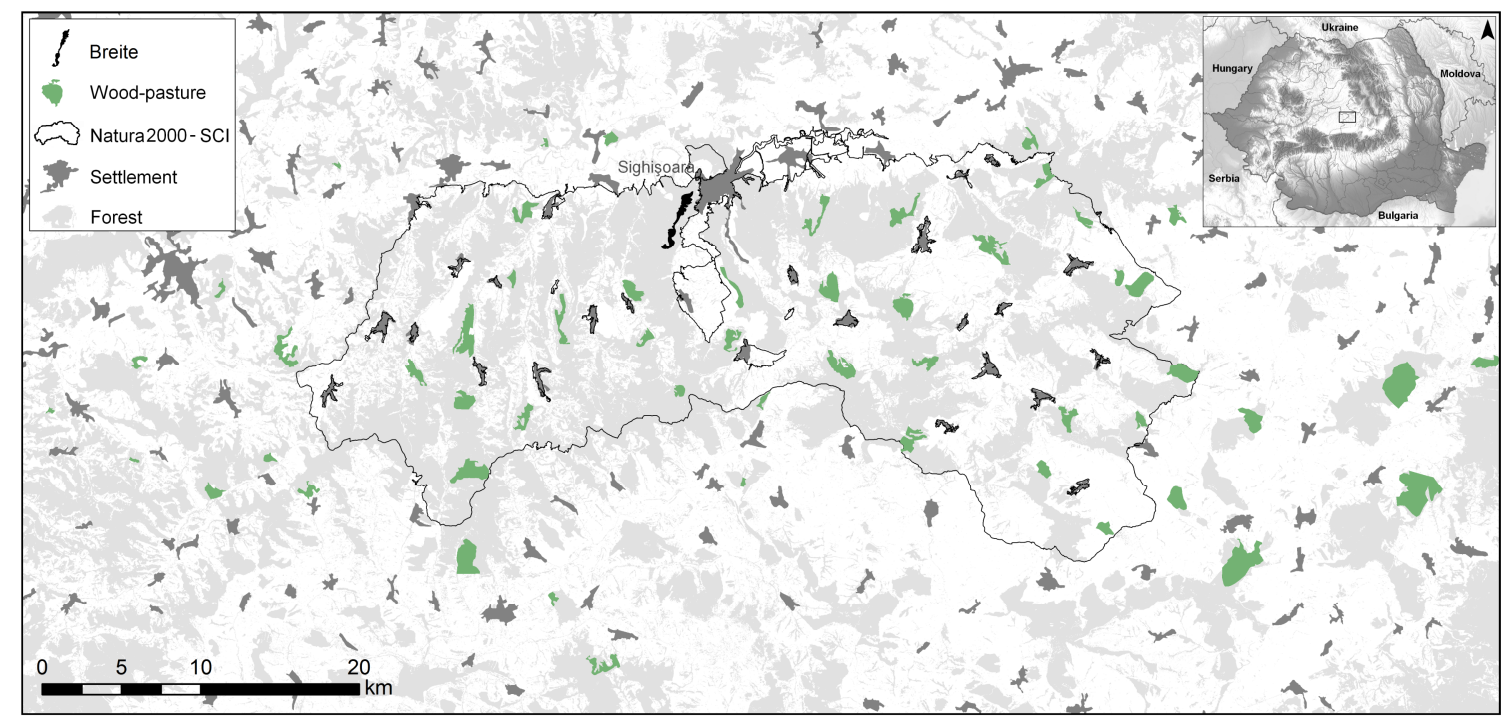

Figure 1. The distribution of wood-pastures in Southern Transylvania, central Romania based on Hartel et al. 2013 and Roellig et al. 2013. The location of the Breite is highlighted.

\section{Documenting land-use history and traditional management practices}

Several sources were used to reconstruct the management history and to obtain a clear picture regarding the former management practices applied in wood-pastures, and the Breite wood-pasture in particular. (i): Land registers, namely the $1^{\text {st }}$ Ordnance Survey (OS) of the Habsburg Empire, also known as the Josephinian land register (1769-1773, scale 1: 28 800) and the $3^{\text {rd }}$ OS of the Habsburg Empire (1869-1873, scale 1: 25 000), in order to determine the approximate period of appearance of present-day wood-pastures. (ii) Publications based on the analysis of a relatively large number of historical $\left(16-19^{\text {th }}\right.$ c.) common land management rules and regulations applied by the Transylvanian Saxons and kept in archives (Dorner 1910; Nägler et al., 1984; Oroszi, 2004; Schuller, 1895; Siegmund, 1948). (iii) Papers from the period when woodpasturing was still widespread in the region (Belházy, 1888; Bíró, 1910; Földes, 1895; Zsarolyáni, 1897). (iv) Books, papers and reports discussing the management practices applied in European wood-pastures in general (Bergmeier et al., 2010; Crofts and Jefferson, 1999; Haraszthy et al., 1997; Rackham, 1980; Rich et al., 2005; Rotherham, 2013; Stiven, 2009; Vera, 2000). (v) Oral evidence - personal communication of locals. 


\section{Results and discussion}

\section{History and development of wood-pastures}

Although wood-pasturing was probably applied by Saxons already upon their arrival in the $12^{\text {th }}-13^{\text {th }} \mathrm{c}$., as it was a widespread practice in Europe in those times (Rotherham, 2013; Vera, 2000), the first regulations regarding grazing in woodlands in this region are from the $16^{\text {th }}$ c. (Oroszi, 2004). For example, the Breite was already an established common grazing area in the early- $18^{\text {th }}$ c. (the first written record dates from $1721-$ Siegmund, 1948), but is shown on the $1^{\text {st }}$ OS $\left(18^{\text {th }}\right.$ c.) still as closed canopy woodland. However, on the $3^{\text {rd }}$ OS $\left(19^{\text {th }}\right.$ c. $)$ it is depicted as an open grazing area with scattered trees (Öllerer, 2013), meaning that it gained its present open wood-pasture character by the second half of the $19^{\text {th }}$ century. The comparison of the two land cover maps shows that the history of many wood-pastures from the study area is similar, their present open character being relatively recent, dating most probably from the second half of the $19^{\text {th }}$ c. However, it is plausible to assume, based on the study of the Saxon land-use regulations (Dorner 1910; Nägler, 1984; Schuller, 1895), and of the management history of the Breite (Öllerer, 2013) that the majority of these sites were developed following the opening up of previously grazed woodlands, which shows the continuity of this practice in Southern Transylvania.

\section{Importance for the local community}

Most wood-pastures are located in close distance to villages (around $1.2 \mathrm{~km}$, Hartel et al., 2013) and the majority of villages in the area have at least one wood-pasture, showing the importance of this land-use for the traditional Saxon communities.

As pasturing and certain types of forest uses, wood-pasturing was also done together by the inhabitants of individual communities, being part of the allmende (the common land) and their use was governed by the communal authorities (Dorner, 1910). Adherence to the rules was given much importance, providing a strict frame for everyday life (Dorner, 1910; Nägler, 1984; Schuller, 1895); no one could use the land against community interest, ensuring what we call nowadays "sustainable use" of land.

Trees from wood-pastures were grown not for their timber, but for their fruits (mainly acorns, but wild fruit trees were also widespread) (Dorner, 1910) and for maintaining the soil quality of pastures (nutrients and moisture) in order to provide sufficient fodder for livestock (Belházy, 1888). This explains why trees were left to grow old and that nowadays the majority of veteran trees in Southern Transylvania can be found in wood-pastures (Hartel et al., 2013). Such old trees were named "mothertree", "seed-tree", while stand continuity was ensured by sapling protection through temporary prohibition of grazing, fencing, scrub management and by plantings (Belházy, 1888; Dorner, 1910). A part of the acorns were collected in October, just before the pannaging season (October-December, around St. Nicholas's Day) and transported to manor game parks and nursery gardens, seedlings being planted in order to secure stand regeneration of these forests (Földes, 1895).

Different management practices were finely tuned in order to allow the regeneration of pasture plants, and were therefore applied only in certain periods, in close connection with several feast-days, adapted yearly to the particular weather conditions (Fig. 2), showing how land management was an integral part of the spiritual and cultural aspects of life in Saxon communities (Dorner, 1910; Nägler, 1984; Schuller, 1895;). 
Nowadays the management system is much simplified (Fig. 2), and wood-pastures are often maintained by individuals who rent the land, raising several socio-economical questions regarding their sustainable use in the future (Sutcliffe et al., 2014).

\section{The practice of ground vegetation management in the past and the present}

\section{Grazing}

In the times when present-day wood-pastures were still closed canopy grazed forests, pigs were the main grazers, followed by cattle and horses (Dorner, 1910; Oroszi, 2004). When acorn production was seen as insufficient for renewal, pigs were not allowed to graze in the forest (Oroszi, 2004). Contrary to the traditional practice when common grazing was usually restricted to the period between the feast of St. George $-24^{\text {th }}$ April and St. Martin - $11^{\text {th }}$ November nowadays the grazing period is longer (Fig. 2).

Stocking rates (numbers and proportions) also went through major changes. Unfortunately we have no clear data regarding previous stocking rates in any of the wood-pastures in particular, however, there are several sources listing the overall number of grazing animals that were allowed out in pastures, including wood-pastures. For example, these were the following in Feldioara in 1887: buffalos and cattle - 1600, pigs -700 , horses and foals -560 , sheep - 400 (Oroszi, 2004). Therefore Saxons preferred traditionally cattle, buffalo, horses and pigs, while sheep were also present, but in a considerably smaller amount (Dorner, 1910). Even at the beginning of the $20^{\text {th }}$ century, large scale grazing with sheep was present only in marginal areas in Southern Transylvania (Dorner, 1910). On several occasions, grazing with sheep was allowed only before St. George's Day ( $24^{\text {th }}$ April) and from the end of August, but often only after St. Michael's Day ( $29^{\text {th }}$ September), the period in between the areas were mowed or grazed with cattle and horses (Dorner 1910; Schuller, 1895; Siegmund, 1948, Fig. 2). The number of goats increased significantly for the first time at the turn of the $18-19^{\text {th }}$ century, henceforward this species became subject to several restrictions, being even banned from several localities (Oroszi, 2004).

Wood-pastures were therefore grazed by mixed livestock, mainly cattle and pigs, while sheep and goats were often subject to regulations. However, stocking rates recorded in the study region show that sheep became the main grazers. The recent survey showed that nowadays $60 \%$ of wood-pastures are grazed only by sheep, $21 \%$ only by cattle and only $14 \%$ by mixed (cattle, sheep, buffalo) livestock (Hartel et al., 2013, Fig. 2). In the 2008-2010 period, the following stocking rates of grazers (average numbers) have been recorded in the Breite wood-pasture during the vegetation season: sheep - 150, goats -30 (up to 120 according to personal communication of the local ranger); cattle - 10; horses -3 .

Between 1995 and 2010 the number of cattle dropped by about $38 \%$ whereas the number of sheep increased approximately by $25 \%$ in the region, and sheep outnumber cattle by 9.62 times (Romanian National Institute of Statistics, reports for the 19952009 period). Farmers in Romania have the opportunity to receive agri-environment payments, which favor the increase in the number of sheep. On the other hand, the modifications of regulations regarding dairy-products made cattle husbandry unprofitable for local farmers, resulting in the decrease of cattle stocking rates. This situation is in accordance with the general trend reported for wood-pastures (Rotherham, 2013) and pastures in general across Europe (Isselstein et al., 2005) and started more than a century ago (Földes, 1895). 


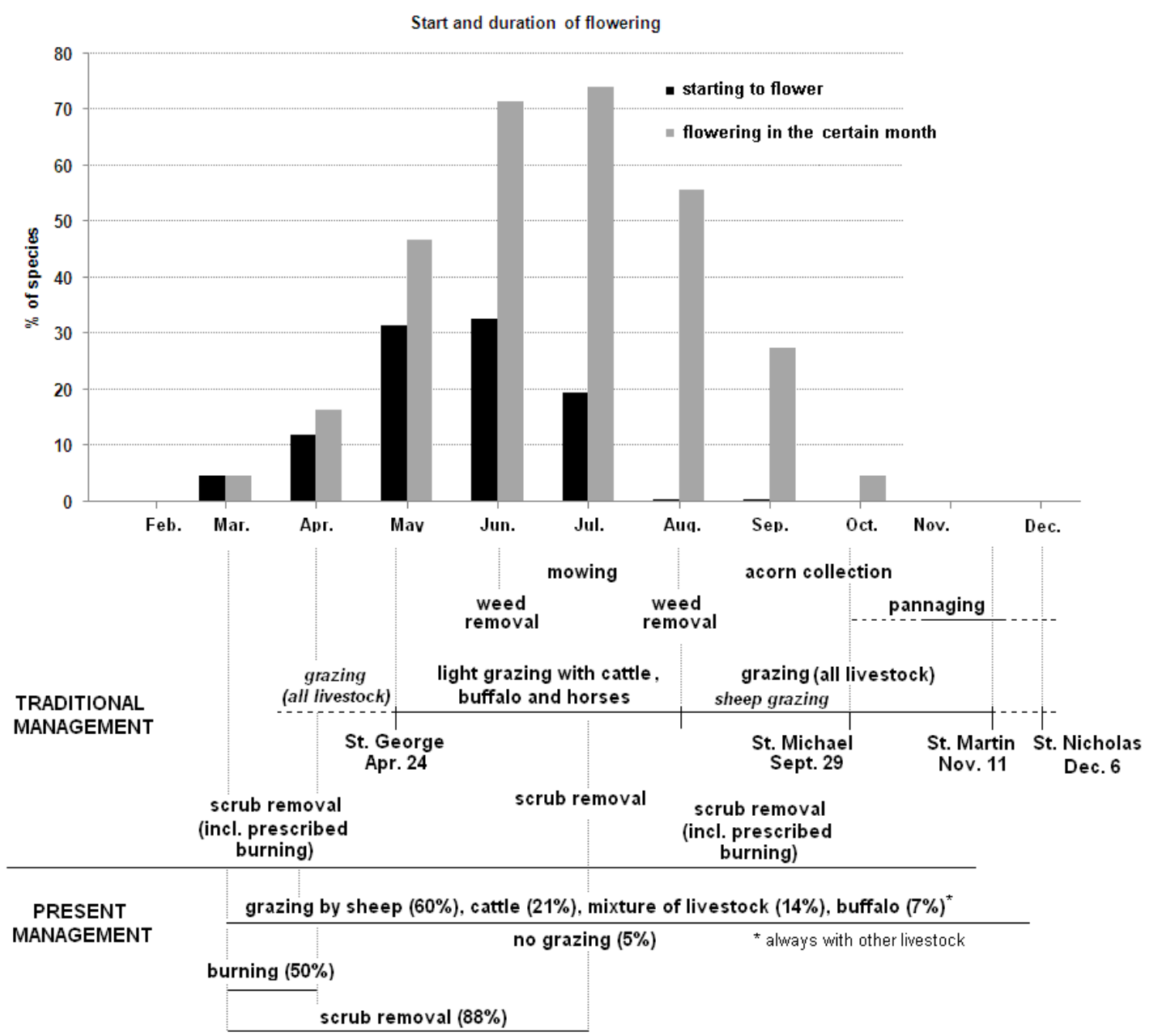

Figure 2. The percent of vascular plant species identified in the Breite wood-pasture flowering in different months and the traditional and present management regimes applied in the woodpastures from Southern Transylvania. Complete species list is available in Öllerer (2012). Data on flowering periods were obtained from Ciocârlan (2009). Numerical data on present management were obtained from Hartel et al. (2013).

Saxons had strict rules also regarding the order in which animals were allowed to graze, determined by the economic importance of the different herds and their feeding habits. Cattle and horses, selective grazers, were left to graze first, followed by buffalos (upon their introduction in the $18^{\text {th }} \mathrm{c}$.) and pigs. Sheep and goats were considered livestock of secondary importance in the Saxon society (Dorner, 1910). Besides, both are less selective grazers, causing large damage to the herbaceous vegetation and tree saplings, therefore they were the last allowed to graze, and only in certain periods, but often were completely banned out from wood-pastures (Dorner, 1910, Fig. 2).

\section{Mowing and scrub removal}

Although the characteristic management practice of the ground vegetation in woodpastures is grazing, it was regularly completed by mowing (Siegmund, 1948). This practice is nowadays practically abandoned; the occasional events do not have an 
accountable influence on the ground vegetation. However, there are certain factors that seem to favor the reintroduction of mowing. Traditional mowing was done relatively late in the year (end of June-July, the latter being known as the Heumonat, meaning "hay month", Fig. 2), which corresponds with the recent regulations prescribed for HNV farming systems, that allow mowing only after the $1^{\text {st }}$ of July (Agency for Payments and Intervention in Agriculture, Romania). Discussions with local farmers showed that they believe that the species potential of the ground vegetation of woodpastures could be brought out only by combining grazing and mowing. They also noted that mowing and hay gathering for fodder would allow maintaining the animals in stables for longer periods, therefore decreasing the number of situations when animals have to be taken out to graze before the traditional start of the grazing season (Holban, 2011), situations which often damage the sprouting plants.

Several species with relatively low palatability (ex. Cirsium arvense, C. vulgare, D. caespitosa and Juncus effusus) showed major expansion in the last years in the Breite wood-pasture, following the abandonment of regular mowing and shift of grazing regime from the traditional system (Öllerer, 2012, pers. comm. of locals), a trend observed also in other sites (Öllerer, unpublished). This brings into attention the importance of combining grazing with mowing (Matejkova et al., 2003), which is in accordance with the traditional practices applied in wood-pastures in general (Crofts and Jefferson, 1999) and also in the study area (Siegmund, 1948).

Ground vegetation was regularly cleared of shrubs in order to allow free movement for animals (Belházy, 1888). In order to avoid encroachment due to secondary succession, saplings were cut off periodically in the middle of the summer, when the regeneration capacity is decreased due to the torrid weather. In this situation new shoots were too weak at the beginning of the cold season and would freeze; besides, young shoots are more easily consumed by grazing animals (Bíró, 1910). Removed shoots and branches were gathered and laid over the shrubs, this cover hampering the development of new shoots. Weeds grown in more intensely grazed areas were cut with a spade or hoe twice a year (in June and August) before flowering. Cattle droppings were left to dry out and later spread across the area in order to avoid the concentration of nutrients (Bíró, 1910). Well-rotted farmyard manure was periodically applied in spring and autumn for pasture improvement (Dorner, 1910; Nägler, 1984). Because fallen leaves have a high mineral content that is essential for herbaceous plants, cattle were left to walk across the area during humid days in late autumn in order to trample the leaves, helping in this way the formation of a thick humus layer (Zsarolyáni, 1897).

The practice of scrub removal is nowadays reactivated due to the agri-environment financial incentives for cleaning pastures, evidence of which were noticed in $88 \%$ of the inventoried wood-pastures (Hartel et al., 2013; Fig 2).

\section{Pasture burning}

The results presented above show that in the traditional management system the ground vegetation of wood-pastures was subject to various disturbances. This extensive and complex management lead to the biodiversity that is aimed to be conserved nowadays by including the area under Natura 2000 regulations and considering it as of high nature value, biodiversity which is potentially threatened by the ongoing changes in stocking rates, extended grazing period and abandonment of certain practices. 
One of the main changes in the management regime is represented by the increasing incidence of spring pasture burnings. Although pasture burning was traditionally applied for the removal of unwanted vegetation (Dorner, 1910), it was done in closely controlled conditions, whereas spring pasture burnings encountered in $50 \%$ of the wood-pastures from the study region were uncontrolled fire events (Hartel et al., 2013). A recent study on the effects of spring pasture burnings showed that the negative effects prevailed among species belonging to Asteraceae and Poaceae (Ruprecht et al., 2013), two of the most common plant families of Transylvanian open habitats, including the study region (Öllerer 2012; Oroian, 2009) and called for caution in the use of fire as a management tool.

Pasture burnings are seen as a cost-effective and potential alternative management method to the traditional labor-intensive grazing and mowing (Valkó et al, 2014). Although burnings can contribute to the maintenance of the open character of grasslands by preventing shrub encroachment and accumulation of dry biomass, they often cause undesired changes in species abundance and composition, including the favoring of weeds and invasive species (Ruprecht et al., 2013; Deák et al, 2014; Valkó et al, 2014 and references therein). Albeit being often applied for shrub control, burning can still have a positive feed-back also on woody species (Deák et al, 2014), favoring the development of new shoots (e.g. on hornbeam - Öllerer, pers. obs, one of the main species encroaching wood-pastures in the study region - Öllerer, 2013). Besides, burning only removes biomass, whereas grazing and mowing have more complex effects on the ground vegetation due to the various associated disturbances (Table 1).

Table 1. Summary of characteristic effects of different management practices on factors influencing grassland and habitat diversity of wood-pastures in Southern Transylvania based on field observations. The situations when fire can cause undesired changes from a conservation management perspective are marked with *.

\begin{tabular}{|c|c|c|c|c|}
\hline \multirow{2}{*}{$\begin{array}{l}\text { Factors influencing grassland and } \\
\text { habitat diversity in wood-pastures }\end{array}$} & \multicolumn{4}{|c|}{ Management practice } \\
\hline & $\begin{array}{c}\text { extensive } \\
\text { cattle grazing }\end{array}$ & $\begin{array}{c}\text { extensive } \\
\text { sheep grazing }\end{array}$ & mowing & burning \\
\hline $\begin{array}{l}\text { phytomass removal } \\
\text { litter accumulation } \\
\text { creation of vegetation gaps / mosaics }\end{array}$ & $\begin{array}{l}\text { selective } \\
\text { negative } \\
\text { positive }\end{array}$ & $\begin{array}{l}\text { less selective } \\
\text { negative } \\
\text { positive }\end{array}$ & $\begin{array}{l}\text { unselective } \\
\text { negative } \\
\text { no / positive }\end{array}$ & $\begin{array}{l}\text { less selective } \\
\text { negative } \\
\text { no/ } \\
\text { positive }\end{array}$ \\
\hline spatial and temporal heterogeneity & positive & positive & positive & positive \\
\hline shrub encroachment $*$ & negative & negative & negative & $\begin{array}{l}\text { negative / } \\
\text { positive }\end{array}$ \\
\hline spread of weed and invasive species * & negative & negative & negative & $\begin{array}{l}\text { negative / } \\
\text { positive }\end{array}$ \\
\hline seed dispersal $*$ & positive & positive & no / positive & $\begin{array}{l}\text { positive/ } \\
\text { negative }\end{array}$ \\
\hline available nutrients & positive & positive & no / negative & positive \\
\hline $\begin{array}{l}\text { soil disturbance (trampling, hollows, } \\
\text { temporary water bodies) }\end{array}$ & positive & $\begin{array}{l}\text { positive, less } \\
\text { considerable }\end{array}$ & no / positive & no \\
\hline survival of veteran oaks $*$ & positive & positive & positive & negative \\
\hline oak regeneration $*$ & positive & $\begin{array}{l}\text { negative in the } \\
\text { lack of fencing }\end{array}$ & positive & negative \\
\hline
\end{tabular}


Mowing results in a relatively uniform foliage removal (plants that exceed certain height are cut at the same level) and favours the development of a more or less stable species pool while selective removal through grazing implies also other disturbances (trampling, soil compaction, urine and dung deposition etc.), which results in a greater species dynamics (Herben and Huber-Sannwald, 2002).

Cattle movement and grazing favor the appearance and maintenance of ephemeral wetlands. Vegetation removal through grazing or mowing increases the hydroperiod (length of inundation), while exclusion of grazers leads to the decline of plant species diversity and increasing abundance of non-native species (Marty, 2005). In the lack of a permanent water source excepting rainfall, such ephemeral wetlands are essential for the maintenance of mesophile meadows, which are characteristic for the wood-pastures from the study region (Hartel et Moga, 2010), and have been shown to support vascular plant species and communities of conservation interest (Öllerer, 2012; 2013). Temporary water bodies contribute substantially to the overall biodiversity (Boix et al., 2012) of wood-pastures and of the wider region, several species and communities being limited to these habitats (Hartel et Moga, 2010; Öllerer, 2013).

Besides, uncontrolled pasture burnings have a strong negative impact on the keystone (Manning et al, 2006) veteran trees, which usually die after such events. Therefore, albeit it has a good potential in controlling undesired vegetation, pasture burning in its present form is not a viable substitute for grazing and mowing in woodpastures.

\section{Conclusions and implications for biodiversity conservation}

This study showed that traditional uses of wood-pasture in Southern Transylvania correspond to the general practice applied in other regions (Bergmeier, 2010; Rotherham, 2013; Vera, 2000), and main uses included cattle and pig grazing, mowing, while sheep were subject to strict regulations (Dorner, 1910; Oroszi, 2004).

Field experience and discussions with local herders showed that traditional practices are gradually disappearing. However, only $5 \%$ of the surveyed wood-pastures lacked grazing (Hartel et al., 2013), which can be seen as a sign of ongoing interest for this habitat type, albeit present management lacks much of the complexity of previous uses.

Although wood-pastures per se are not legally recognized for their key ecological role, more than half of those from the study region are covered by Natura 2000 regulations regarding management and maintenance of biodiversity, therefore it is important to stress out that it is less economically demanding to continue the practices that maintain high species richness than to apply costly conservation measures, since farmers with high traditional practices and underlying knowledge have positive attitudes towards conservation (Shen et al., 2012). Similarly to other traditionally managed regions (Babai et Molnár, 2014), local farmers have the willingness to continue traditional management, unless if it is economically disadvantageous (Holban, 2011).

Besides the economical reasons, the gradual disappearance of the traditional management regime applied in wood-pastures from Southern Transylvania is also the result of the loss of knowledge rooted in the understanding of site history, due to the disrupted social structure following the mass emigration of Saxons in the $20^{\text {th }}$ century (Gündisch, 1998). This situation creates an identity-gap between land(scape), its history and the new owners, changes in the structure of the local populations leading to transmission failures (Ostrom, 1994). The general European trend towards individual 
management of the commons represents nowadays a social and economical challenge for the future development of this region, including the biodiversity conservation issues (Sutcliffe et al, 2014). Therefore, mediated transfer of knowledge underlying traditional land-use practices is essential.

A proactive management approach is needed that supports learning initiatives for farmers and shapes and promotes their attitude towards valuing and maintaining traditional ecological knowledge and the ecosystem services provided by traditional landscapes. Therefore, the integration of biodiversity conservation, rural development and agricultural policy is seen as the way forward in the attempt of maintaining the social, cultural and biodiversity values of such landscapes (Fischer et al., 2012; Babai and Molnár, 2014; Schmitt and Rákosy, 2007; Mikulcak et al., 2013).

Acknowledgements. The author is grateful to Erika Schneider-Binder, Tibor Hartel, Anna-Mária Csergő and Zsolt Molnár for the various discussions regarding wood-pasture management and pasturing sytems. Locals from Sighişoara who provided valuable information regarding the former use of the Breite woodpasture: Erika Schneider-Binder, Alexandru Goța, Kuno Martini, Walter Lingner and Dan Pasca (ranger). Zsolt Molnár, Laura Sutcliffe and Marlene Roellig made helpful comments on previous versions of the manuscript. The suggestions of Eszter Ruprecht and Orsolya Valkó are also acknowledged. Marlene Roellig kindly helped with Fig. 1. Different stages of this study were funded by the Mihai Eminescu Trust, the Swedish Biodiversity Centre and the Institute of Biology-Romanian Academy through the project "Taxonomic and chorological studies on flora and fauna species from Romania".

\section{REFERENCES}

[1] Akeroyd, J., Page, N. (2006): The Saxon villages of Southern Transylvania: Conserving biodiversity in a historic landscape. - In: Gafta, D., Akeroyd, J. R. (ed.): Nature conservation: concepts and practice. Springer, Heidelberg.

[2] Babai, D., Molnár, Zs. (2014): Small-scale traditional management of highly species-rich grasslands in the Carpathians. - Agriculture, Ecosystems and the Environment (in press), http://dx.doi.org/10.1016/j.agee.2013.08.018.

[3] Behre, K-E. (1988): The rôle of man in European vegetation history. - In: Huntley, B., Webb, T. III (ed.): Vegetation history. Handbook of vegetation science, vol. 7. Kluwer Academic Publishers, Dordrecht.

[4] Belházy, E. (1888): A legeltetésre szolgáló erdőkről [Regarding the forests used for grazing]. - Erdészeti Lapok 27(4): 281-299.

[5] Bergmeier, E., Petermann, J., Schröder, E. (2010): Geobotanical survey of wood-pasture habitats in Europe: diversity, threats and conservation. - Biodiversity and Conservation 19: 2995-3014.

[6] Bíró, J. (1910): A legelö-erdők berendezéséről és gyepesítéséről, különös tekintettel a Székelyföldre [On the configuration and lawning of wood-pastures, with special consideration on the Székely land]. - Erdészeti Lapok 49-2: 38-69.

[7] Boix, D, Biggs, J, Cereghino, R, Hull, AP, Kalettka, T, Oertly, B. (2012): Pond research and management in Europe: "Small is Beautiful". - Hydrobiologia 689: 1-9.

[8] Bugalho, M. N., Caldeira, M. C., Pereira, J. S., Aronson, J., Pausas J. G. (2011): Mediterranean cork oak savannas require human use to sustain biodiversity and ecosystem services. - Frontiers in Ecology and the Environment 9: 278-286.

[9] Ciocârlan, V. (2009): Flora ilustrată a României [The illustrated flora of Romania]. Editura Ceres, Bucureşti.

[10] Coldea. G. (1992): Vegetaţia Transilvaniei şi Maramureşului [The vegetation of Transylvania and Maramureş]. - In: Ivan, D. (ed.): Vegetaţia României, Editura Technică Agricolă, Bucureşti. 
[11] Crofts, A., Jefferson, R.G. (1999): Grassland management in wood-pasture and parkland. - In: Crofts, A., Jefferson, R.G. (ed.): The lowland grassland management handbook. 2nd edition. English Nature, The Wildlife Trusts.

[12] Deák, B., Valkó, O., Török, P., Végvári, Zs., Hartel, T., Schmotzer A., Kapocsi, I., Tóthmérész, B. (2014): Grassland fires in Hungary - Experiences of nature conservationists on the effects of fire on biodiversity. - Applied Ecology and Environmental Research (in press).

[13] Dorner, (Enesei) B. (1910): Az erdélyi szászok mezőgazdasága [The agriculture of the Transylvanian Saxons]. - Györ.

[14] EEA - European Environmental Agency (2008): The Natura 2000 network across biogeographical regions of the European Union - map.

[15] Fischer, J., Hartel, T., Kuemmerle, T. (2012): Conservation policy in traditional farming landscapes. Conservation Letters 5: 167-175.

[16] Fischer, J., Scott, J., Law, S.B. (2010): The disproportionate value of scattered trees. Biological Conservation 143: 1564-1567.

[17] Földes, J. (1895): A legelő-erdők berendezése, okszerü kezelése, használata és felújítása [The arrangement of wood-pastures, their management, use and renewal]. - Erdészeti Lapok 34: 30-72, 157-212, 278-329, 395-432, 526-536.

[18] Gündisch, K. (1998) Siebenbürgen und die Siebenbürger Sachsen [Transylvania and the Transylvanian Saxons]. Studienbuchreihe der Stiftung Ostdeutscher Kulturrat 8, Munich.

[19] Halada, L., Evans, D., Romão, C., Petersen, J-E. (2011): Which habitats of European importance depend on agricultural practices? - Biodiversity and Conservation 20: 23652378.

[20] Haraszthy, L., Márkus, F., Bank, L. (1997): A fás legelők természetvédelme [The nature conservation of wood-pastures]. - WWF-füzetek 12.

[21] Hartel, T., Dorresteijn, I., Klein, C., Máthé, O., Moga, C.I., Öllerer, K., Roellig, M., von Wehrden, H., Fischer, J. (2013): Wood-pastures in a traditional rural region of Eastern Europe: Characteristics, management and status. - Biological Conservation 166: 267-275.

[22] Hartel, T., Moga, C.I. (2010): Manual de bună practică în managementul habitatelor de pajişte cu arbori seculari [Good-practice guidebook for the management of wood-pasture habitats with veteran trees]. - Fundaţia Mihai Eminescu Trust, Sighişoara.

[23] Herben, T., Huber-Sannwald, E. (2002): Effects of management on species richness of grasslands: sward scale processes lead to large-scale patterns. - In: Durand, J.L., Emile, J.C., Huyghe, C., Lemaire, G., (ed.) Multifunction Grasslands, Quality Forages, Animal Products and Landscapes. Proceeding of the 19th general meeting of the European Grassland Federation, British Grassland Society, Reading.

[24] Holban, L. (2011): Îngrijirea şi valorificarea pajiştilor cu arbori seculari - Ghid pentru fermieri [The management and utilization of ancient wood-pastures - Guide for farmers]. - Fundaţia Mihai Eminescu Trust, Sighişoara.

[25] Isselstein, J., Jeangros, B., Pavlu, V. (2005): Agronomic aspects of biodiversity targeted management of temperate grasslands in Europe - A review. - Agronomy Research 3(2): 139-151.

[26] Lindenmayer, D.B., Lawrence, W.F., Franklin, J.F. (2012): Global decline in large old trees. - Science 338 (6112): 1305-1306.

[27] Manning, A. D., Fischer, J., Lindenmayer, D.B. (2006): Scattered trees are keystone structures - Implications for conservation. - Biological Conservation 132: 311-321.

[28] Marty, J. (2005): Effects of cattle grazing on diversity in ephemeral wetlands. Conservation Biology 19(5): 1626-1632.

[29] Matejkova, I., van Diggelen, R., Prach, K. (2003): An attempt to restore a Central European species-rich mountain grassland through grazing. - Applied Vegetation Science 6: 161-168. 
[30] Middleton, B.A. (2013): Rediscovering traditional vegetation management in preserves: trading experiences between cultures and continents. - Biological Conservation 158: 271279.

[31] Mikulcak, F. Newig, J., Milcu, A.I., Hartel, T., Fischer, J. (2013): Integrating rural development and biodiversity conservation in Central Romania. - Environmental Conservation 40(2): 129-137.

[32] Moga, C.I., Hartel, T., Öllerer, K. (2009): Ancient wood-pasture as a habitat for the endangered tree pipit Anthus trivialis. - Biologia 64: 1-5.

[33] Nägler, T., Schobel, J., Drotleff, K. (1984): Geschichte der siebenbürgisch-sächsischen Landwirtschaft [History of the Transylvanian Saxon agriculture]. - Kriterion Verlag, Bukarest.

[34] Öllerer, K. (2012). The flora of the Breite woodpasture (Sighişoara, Romania). Brukenthal Acta Musei 7(3): 589-604.

[35] Öllerer, K. (2013): The vegetation of the Breite woodpasture (Sighişoara, Romania) history, current status and prospects. - Brukenthal Acta Musei 8(3): 547-566.

[36] Oroian, S. (2009): Flora şi vegetaţia satelor săseşti din Transilvania [The flora and vegetation of the Saxon villages from Transylvania]. - Editura University Press, TârguMureş.

[37] Oroszi, S. (2004): Az erdélyi szászok erdőgazdálkodása [The forest management of the Transylvanian Saxons]. - Erdészettörténeti közlemények 63: 1-153.

[38] Ostrom, E. (1994): Institutional analysis, design principles and threats to sustainable community governance and management of commons. - In: Pomeroy, R.S. (ed.): Community management and common property of coastal fisheries in Asia and the Pacific: concepts, methods and experiences. ICLARM Conference Proceedings, p. 45.

[39] Rich, T., Peterken G., Tucker, G., McMeechan, F., Dobson, D. (2005): Habitat requirements and issues. Lowland wood-pastures and parkland. - In: Hill, D., Fasham, M., Tucker, G., Shewry, M., Shaw, P. (ed.) Handbook of Biodiversity Methods. Survey, Evaluation and Monitoring. Cambridge University Press, Cambridge.

[40] Rigueiro-Rodríguez, A., McAdam, J., Mosquera-Losada M.R. (ed.) (2009): Agroforestry in Europe. Current Status and Future Prospects. - Advances in Agroforestry 6. Springer.

[41] Roellig, M., Dorresteijn, I., Hartel, T., von Wehrden, H., Hanspach J., Fischer, J. (2013): Bear activity in traditional wood-pastures in southern Transylvania, Romania (submitted manuscript).

[42] Rois-Díaz, M., Mosquera-Losada, R., Rigueiro-Rodríguez, A. (2006): Biodiversity indicators on silvopastoralism across Europe. Technical Report 21. - European Forest Institute.

[43] Rotherham, I.D. (ed.) (2013): Trees, forested landscapes and grazing animals: A European perspective on woodlands and grazed treescapes. - Routledge, London.

[44] Ruprecht, E., Fenesi, A., Fodor, E.I., Kuhn, T. (2013): Prescribed burning as an alternative management in grasslands of temperate Europe: the impact on seeds. - Basic and Applied Ecology 14(8): 642-650.

[45] Saláta, D., Horváth, S., Varga A. (2009): Az erdei legeltetésre, a fás legelők és legelöerdök használatára vonatkozó 1791 és 1961 közötti törvények [Laws regulating grazing in forests, use of grazed forests and wood pastures in Hungary between 1791 and 1961]. - Tájökológiai Lapok 7(2): 387-401.

[46] Saláta, D., Wichmann, B., Házi, J., Falusi, E., Penksza, K. (2011): Botanikai összehasonlító vizsgálat a cserépfalui és az erdőbényei fás legelőn. - AWETH 7(3): 234-262.

[47] Schmitt, T., Rákosy, L. (2007): Changes of traditional agrarian landscapes and their conservation implications: a case study of butterflies in Romania. - Diversity and Distribution 13: 855-862. 
Öllerer: The ground vegetation management of wood pastures in Romania-Insights in the past for conservation management in the

[48] Schuller, G.A. (1895): Aus der Vergangenheit der Siebenbürgen-Sächsischen Landwirtschaft [From the history of the Transylvanian Saxon agriculture]. Buchbruderei W. Krafft, Sibiu, Romania.

[49] Shen, X., Li, S., Chen, Ny., Li, S., McShea, W.J., Lu, Z. ( 2012): Does science replace traditions? Correlates between traditional Tibetan culture and local bird diversity in Southwest China. - Biological Conservation 145: 160-170.

[50] Siegmund K. (1948): Der Stadtwald von Schäßburg, seine Lebensgeschichte [The town forest of Sighişoara- Schäßburg and its and its history]. - Archiv der Siebenbürgischen Bibliothek in Gundelsheim. Tiposcript.

[51] Stiven, R. (2009): Management of ancient wood pasture. Guidance note. - Forestry Commission, Scotland.

[52] Sutcliffe L., Öllerer K., Roellig M. (2014): Wood-pasture management in Southern Transylvania (Romania): from communal to where? - In: Hartel, T. and Plieninger T. (ed.): European wood-pastures in transition: A social-ecological approach. Routledge (in press).

[53] Szentes, Sz., Dannhauser, C., Coetzee, R., Penksza, K, (2011): Biomass productivity, nutrition content and botanical investigation of Hungarian Grey cattle pasture in Tapolca basin. - AWETH 7(2): 180-198.

[54] Szentes, Sz., Sutyinszki, Zs., Szabó, G., Zimmermann, Z., Házi J., Wichmann, B., Hufnágel, L., Penksza, K., Bartha, S. (2012): Grazed Pannonian grassland beta-diversity changes due to $\mathrm{C}_{4}$ yellow bluestem. - Cent. Eur. J. Biol. 7(6): 1055-1065.

[55] Valkó, O., Török, P., Deák, B., Tóthmérész B. (2014): Prospects and limitations of prescribed burning as a management tool in European grasslands. - Basic and Applied Ecology (in press), http://dx.doi.org/10.1016/j.baae.2013.11.002.

[56] Whiteman, G., Cooper, W.H. (2000): Ecological embeddedness. - Academy of Management Journal 43: 1265-1282.

[57] Zsarolyáni, M.S. (1897): A legelö-erdők berendezésénél figyelembe veendő tényezőkröl [On the factors that need consideration in the configuration of wood-pastures]. Erdészeti Lapok 36-8: 619-647. 